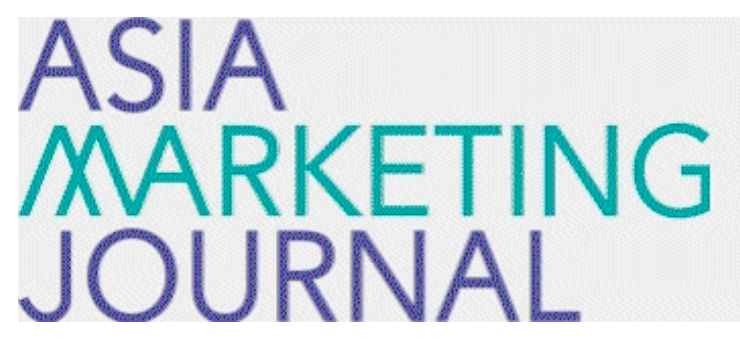

ASIA MARKETING JOURNAL

Volume 14 | Issue 3

Article 2

10-30-2012

\title{
A Case Study of Shinsegae E-mart
}

Chung K Kim

Mi Na Jun

Jeong Soo Han

Kim

Jun Gung Park

See next page for additional authors

Follow this and additional works at: https://amj.kma.re.kr/journal

Part of the Marketing Commons

\section{Recommended Citation}

Kim, Chung K; Jun, Mi Na; Han, Jeong Soo; Kim; Park, Jun Gung; and Kim, Joshua Y (2012) "A Case Study of Shinsegae E-mart," Asia Marketing Journal: Vol. 14 : Iss. 3 , Article 2.

Available at: https://doi.org/10.53728/2765-6500.1487

This Article is brought to you for free and open access by Asia Marketing Journal. It has been accepted for inclusion in Asia Marketing Journal by an authorized editor of Asia Marketing Journal. 


\section{A Case Study of Shinsegae E-mart}

\section{Authors}

Chung K Kim, Mi Na Jun, Jeong Soo Han, Kim, Jun Gung Park, and Joshua Y Kim 


\section{A Case Study of Shinsegae E-mart: How E-mart Became the Number One Distribution Company even against Economic Crisis and the Entry of Walmart?*}

Chung K. Kim ${ }^{* *}$
Mina Jun***
Jeongsoo Han****
Miyea Kim*****
Jungung Park
Joshua Y. Kim*****

The success story of E-mart fascinated many academics and practitioners alike. Though E-mart began as a nameless discount store in Chang-dong. Seoul in 1993, it has transformed itself into a leading distribution company and one of the most powerful brands in Korea. Surprisingly, it achieved the great success against the two crises it met: the national economic crisis and the invasion of the global giant Walmart.

The main objective of this case study is to formally examine how E-mart overcame the two crises. More specifically, this case study highlights the ways with which E-mart turned those difficulties into opportunities for growth.

In our examination of the E-mart case, we could clearly see E-mart's competence and spirit that allowed it to turn crises into advantageous opportunities. E-mart attracted the customers who wanted value-oriented consumption by its positioning as the "Lowest price discount store", when consumer sentiment was frozen under the economic crisis. Furthermore, when a large-scale foreign discount store like Walmart entered the Korea market, E-mart built its core competencies as the "Korean style discount store'. These ingenious positioning and efforts resulted in E-mart taking over their archrival, Walmart, and forced the global Goliath to exit the Korean market.

\footnotetext{
* We would like to thank anonymous people of Shinsegae for their comments.

** Professor, Graduate School of Business, Sungkyunkwan University(kimkim@skkuedu)

*** Doctoral Candidate, Graduate School of Business, Sungkyunkwan University(alskwj@@skku,edu), corresponding author

**** Doctoral Candidate, Graduate School of Business, Sungkyunkwan University(js3916@gmail.com)

***** Doctoral Candidate, Graduate School of Business, Sungkyunkwan University(cally0615@skku.edu)

***** Doctoral Student, Graduate School of Business, Sungkyunkwan University (Jpinbc@skku.edu)

******* Fulbright Scholar, College of Human Ecology, Seoul National University (jyk42@cornell.edu)
} 
The case of E-mart's effective crisis management teaches many important lessons and a few core lessons that apply to many companies. One such lesson is the importance of positioning which enabled E-mart to turn crises into opportunities. Granted, the strategy of positioning as the 'Korean style discount store', or 'Lowest price discount store' was possible due to overall support with cost reduction, development and management of their own system, an apprentice educate system, etc. based on an excellent selection of location of the store and efficient distribution systems. Still, the positioning strategy of E-mart was truly ground breaking in distancing itself from its competitors. The lessons from E-mart will help those companies currently in a stagnant situation or a crisis to turn their obstacles into great success.

Key words: Emart, Walmart, Crisis Management, Foresight Competition, Paradigm Shift

\section{Introduction to the Case}

E-mart, once a nameless brand, made a big mark as the "number one brand of large discount store in Korea." Recently. E-mart opened 135 stores and its sales reached 14 trillion and 400 billion won. After its declaration of separation and independence from Samsung Group in 1991, Shinsagae, the parent company of E-mart. started this leading distribution company by launching the first Korean discount store ever, E-mart, in Chang-dong. Seoul.

Contrary to popular belief, E-mart did not always sail smoothly in becoming the best discount store in Korea. The national economic crisis struck only a few years after E-mart had launched its first store. Thus, many people suffered from the economic crisis, and the overall consumer desire to purchase accordingly froze, proving it to be a difficult situation for $\mathrm{E}$-mart. In addition, as the domestic distribution market completely opened to anyone in the world, the world's biggest discount store Walmart made its entrance into the Korean market in 1998. Many experts expected E-mart, which had started its discount store business just a few years ago, would be badly beat in competition against Walmart, which had a globally-proven, welldeveloped distribution system and enormous financial power. It was apparent that E-mart was embarking upon an uphill battle.

During these hard times, however. E-mart became incredibly successful, transcending public expectations. E-mart ushered in a new period of domestic discount stores, with its great number of stores and volume of sales during the national economic crisis. Furthermore, it waged a hard competition against Walmart and finally beat Walmart Korea in 2006. Since the success during these critical times, E-mart gained the momentum to not only dominate domestically but also to expand globally to growing Asian markets such as the Chinese market. Out of amazement and 
surprise, many people wondered how E-mart overcame such crises.

The main objective of this case study is to formally examine how E-mart overcame the two crises and achieve great success. Therefore, this case study focuses on the crises E-mart experienced and the strategy used to overcome such adversities. More specifically, this case study reviews E-mart's situation during the national economic crisis and Walmart's entrance into
Korean market, and highlights the ways with which E-mart turned those difficulties into opportunities for growth.

To make our analysis more objective and relatable to others, we analyzed the growth of $\mathrm{E}^{-}$ mart with the traditional model of sales growth (see Figure 1). To focus on how a small brand became great, we borrowed the concepts of competitive stages a company undergoes to be become successful. Specifically, Kim (2005, 2011)

〈Figure 1〉 Milestones, Crises, and Positioning Strategies of E-mart through Major Stages of Competition

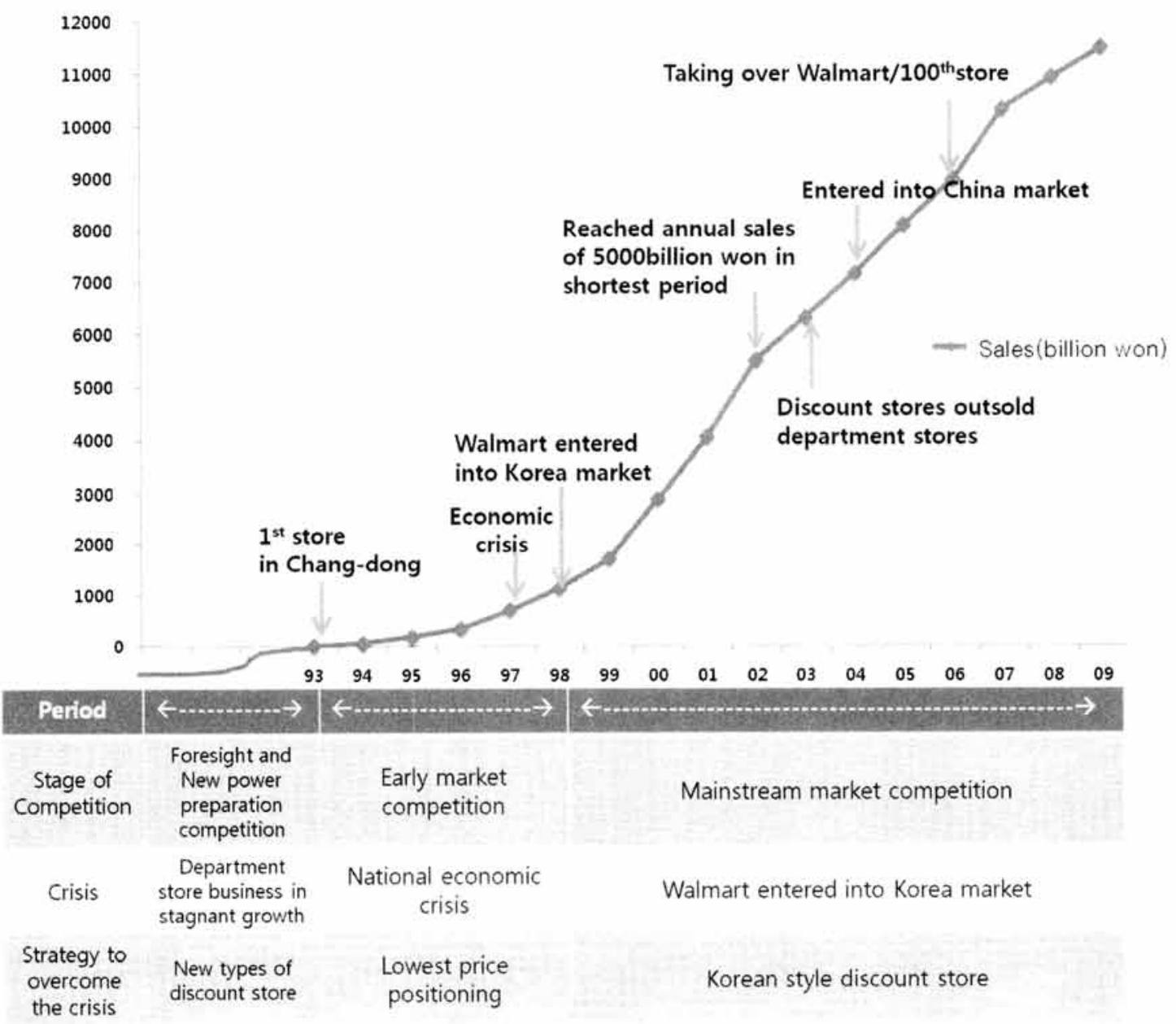


showed that, to reach to the top, a company must prevail in multiple stages of competition: foresight competition, new power preparation competition, early market competition, and mainstream market competition, respectively. This case study focuses on how E-mart triumphed in these competition stages and how E-mart overcame the two crises and became the best discount store in Korea.

\section{The Beginning of E-mart}

Before the first E-mart launched in Changdong, Seoul in 1993, the Korean domestic distribution industry consisted of traditional marketplaces, small scale supermarkets, and department stores resembling large shopping malls. The size of the Korean distribution industry was puny, but more than that, the industry in general severely lacked developed knowledge and know-how on distribution, management system. human resource, etc. Despite such poor conditions. the Korean government preannounced the full opening of the Korean domestic distribution market to foreign companies starting in 1996. On the domestic side, experts claimed that Korean distribution companies should prepare well before foreign companies dominate with huge financial resources and well-developed systems. In this threatening environment. Shinsaegae seized the opportunity to aggressively gain market dominance and launched E-mart, the first discount store in Korea.

\subsection{Foresight and New Power Preparation of Shinsegae}

In the early 1990s, the domestic department industry was facing a recession after the end of the expanding period fueled by the expansion of major companies and new town development. Thus, Shinsegae, the mother conglomerate of E-mart which had already felt pressure from its fierce competition with Lotte, was desperate for a distribution business that could substitute its plummeting department store business. The management began seriously considering the prospect of starting a discount store business. However, while discount stores such as Walmart and $\mathrm{K}$-mart from the US and Carrefour from Europe did well in the Korean market, such discount stores did not strike any particular success in Japan. Thus, Shinsegae held a cynical view about launching a discount store business.

As the new business development team of Shinsegae visited Japan to gain fresh insights for a new business idea, Shinsegae saw hope in a successful discount store business. Three team members who toured Kou's Club in Kobe were shocked when they saw products everywhere stacked high like storage and customers who were selecting among those products. The new business development team members worried whether these kinds of businesses would work 
in Korea, but nevertheless they made a 10-month plan to prepare the launch of E-Mart and got to work. Firstly, upon considering the discount store form of Walmart and the hypermarket form of Carrefour, they decided to employ a discount store concept but with a food(supermarket). general merchandise(discount store), and clothing (outlet) structure together. The name. 'E-mart' was given, with the initial ' $E$ ' representing economic, everyday low price, easy shopping $\&$ count'. E-mart decided not to use Shinsegae's name because Shinsegae was concerned that E-mart's low-priced sales might damage the prestigious and luxurious image of Shinsegae.

\subsection{The Birth of E-mart}

After a complicated course of events, the first E-mart opened in November $12^{\text {th }}, 1994$, Chang-dong. Dobong-gu. Seoul, and it was a two-story building with $4958.7 \mathrm{~m}$ ' scale (see Figure 2). In the first day, 26,800 people visited and total sales for the day was 10 billion eight hundred thousand won. The goods consisted of 20,000 daily necessities with the lowest prices. Despite the concerns, the responses of customers for the new business were certainly not negative. Particularly, young people and those with foreign experience were receptive to the unique construction of store and showed high satisfaction for the low prices of goods.

However, some shortfalls due to operational inexperience were soon discovered. Problems such as lack of ability to receive alternative methods of payment, complicated layout of the store, and lack of signage were found. Also, lack of overall human resources led to a weak backup system. The product re-stocking system was primitive as well. The system required the manager responsible for restocking products to search through the entire store and storage and inform the quantity needed to the suppliers.

E-mart actively responded to solve these problems. E-mart slowly but surely improved by providing comprehensive countermeasures, which included costumer management, handling of

〈Figure 2〉 1st Store of E-mart in Chang-dong. Seoul

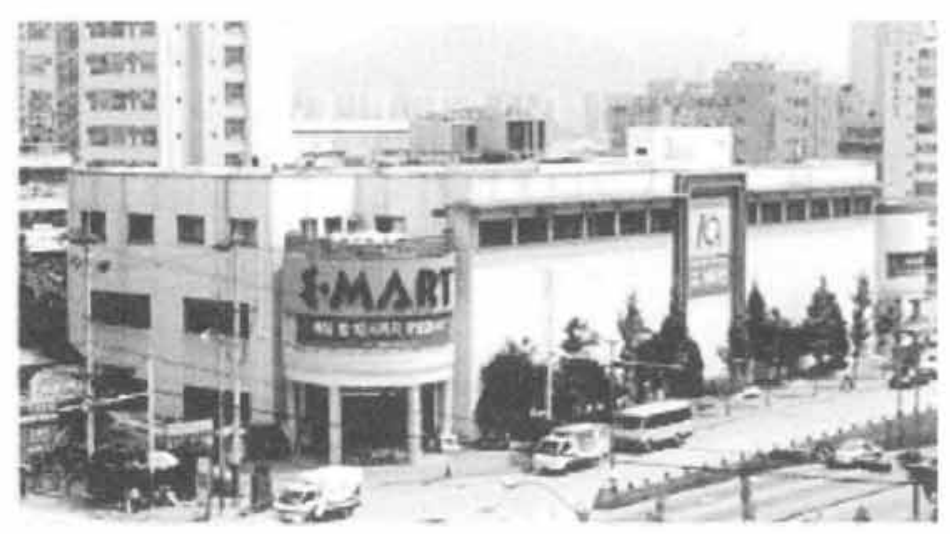


complaints, better service of cashiers. The treatment and attention of Shinsegae toward E-mart began to increase as well.

\section{The 1st Crisis during Early Market Competition}

Since the Asian economic crisis hit Korea in 1997, overall consumer demand froze. Even though E-mart started relatively early in 1993, E-mart encountered the national economic crisis with very little capital, and thus could not expand its business. Nonetheless Shinsegae regarded the growth potential of $\mathrm{E}$-mart highly and prioritized the growth of E-mart by prioritizing and concentrating their investment for E-mart. Also in response to the economic crisis, E-mart positioned itself as the discount store brand that guarantees the lowest prices. This move proved effective for consumers who increasingly sought efficient and value-driven consumption with less spending. Additionally, E-mart prepared for explosive growth in the future by investing the capital gained from clearing out its less lucrative businesses to acquire the sites for establishment of other E-mart stores in the future.

\subsection{The 1st Crisis - National Economic Crisis}

Although, the national economic crisis did not leave anyone unaffected, the middle class felt the most economic damage, and thus, the level of consumption fell at a national scale. With disposable income diminished, consumer demand naturally froze. E-mart, which had sought growth, could not easily expand under such conditions which had already led many large firms to collapse helplessly. A few missteps could fatally blow away the hardly earned chance to successfully develop E-mart's discount store business.

\subsubsection{Increase of value-based consumption due to the shrunk consumer sentiment}

In late 1997 after the national economic crisis had hit, the Korean economy suffered heavy depressions and extremely high unemployment rates that led to an economic and social emergency. The economic recession that started from the foreign exchange crisis in Asia impacted the financial sector, real economy, and society, in order. High prices and high unemployment rates caused the consumer demand for products to rapidly freeze. In response to reduced disposable income, customers tended not to spend on impulse but rather developed a tendency to purchase with purpose and priority based on a set standard and to seek thorough information on products and stores for the most efficient purchases. The customers pursued value-oriented, economical consumption by comparing costs and benefits in terms of price, time, and utility and 
preferred inexpensive shopping spaces such as discount stores and outlet malls that often offered coupons and various methods for discounts. The polarization of consumption patterns is also notable. Although the high income group was not affected seriously, the middle class was swamped. Expenses and earnings of middle classes dropped by nearly $24 \%$ and $30 \%$, respectively.

\subsubsection{The condition of distribution industry}

Due to the overlap of the distribution market opening completely to foreign competition in late 1996 as well as the national economic crisis hitting in 1997, many South Korean companies hanged by a thread. Those companies that borrowed funds from banks to invest in new businesses or to use for internal operations struggled from interest rates larger than 20\%: the old Korean adage, "large horses seldom die' had been undermined as major national companies such as Kia, Hanbo, and HaeTae collapsed. 16 major national firms out of 30 eventually declared bankruptcy.

The conditions facing the distribution industry were not so different. The large department stores, including Blue hill, Nasan and Midopa. went bankrupt as luxurious consumption dwindled. This seismic collapse led to a reorganization of the distribution industry. Sales in Shinsegae's department stores had also been rapidly plummeting, and this seemed like a fitting time for Shinsegae to set a new course for its business. E- mart faced tough situations as well. Investment funds for expansion were lacking even though it was a critical time to bring up the number of stores necessary to maintain the low-price policies. Even though E-mart was the leading discount store, it risked losing its hardly won turf to foreign competitions that came after the distribution markets had opened.

\subsection{The Strategy of E-mart to Overcome the Crisis - Positioning Strategy and Pricing}

Under the circumstances of the national $\mathrm{eco}^{-}$ nomic crisis and frozen consumer sentiment. Shinsegae made a radical decision. Although it was a time that required stability in overall corporate management, the company changed the crisis into an opportunity by aggressively investing based on the newly formed value-driven spending pattern of consumers. The fact that discount stores can break even in about a year. while it normally takes three years for department stores with higher operation and management costs to reach the breakeven point. helped the decision to invest in a discount venue. The decision was also made after the analysis that sales will be higher for E-mart because of consumers' changed preference for low priced, valuedriven goods. E-mart carried out the aggressive business strategy based on the idea that if you take the lead by aggressive management during the recession, your lead will not be easily taken 
away during the booming economy.'

At the base of E-mart's first crisis management strategy was the lowest price positioning that focused on polarized consumption due to frozen consumption and collapse of the middle class. Although discount stores are known for products sold at low prices, E-mart focused all efforts on reducing the cost further and lowering the price as much as possible. E-mart set their catchphrase as EDLP (every day low price) and changed the economic crisis into an opportunity through company-wide concentration and focused decisions.

\subsubsection{Selection and concentration of Shinsegae}

Even though Shinsegae did not have as much difficulty with funding compared to other corporations, they still needed significant amount of funds to solidify the growth base of E-mart. After a long deliberation, Shinsegae employed the 'selection and concentration' strategy for the strategic growth of E-mart. The company decided to foster E-mart in the long run after understanding the consumer trend of value-driven purchase at that time. To this end, Shinsegae started to focus the company-wide resources on E-mart. First, Shinsegae sold Price Club, an American membership wholesale club (MWC) company they were operating at that time and secured 100 million dollars in cash, and also sold Hanmi Card business for additional funds.
Also, they transferred the site they had bought for a department store for future E-mart stores.

\subsubsection{Preparation for EDLP(every day low price) strategy}

In order to establish the EDLP strategy, E-mart carried out three detailed strategies. Firstly, they executed a multi-store strategy to grow the scale of the retailer: secondly, an operation strategy for quick transport: and lastly, a merchandising strategy to promote large variety and high quality products. Gradually, E-mart developed its lowest price positioning.

Economy of scale by opening multiple stores. Preoccupying an advantageous commercial position in distribution is one of the very important factors that decide the winner of the industry. E-mart, with 250 billion won of funds that were secured by aggressive restructuring through selling of Price Club and its credit card business, bought sites that could fit twenty to thirty retailer sites in major commercial districts around the country. Also, Shinsegae modified the projects to build department stores in Sanbon, Jeonju, Haeundae, Jinju, etc., in order to convert those buildings into E-marts. Although the design for department stores was finished already, E-mart's selection and concentration strategy was carried out with determination. Also, after acquiring stores in Guro and Eunpyeong from Geopyeong and New Core at a low price, the company raised the stores as highly lucrative 
sites in sales and profits. Having many stores naturally led to increased purchasing power over the manufacturing industry, and therefore allowed E-mart to cut prices lower by lowering costs of production through economy of scale in manufacturing. Such aggressive and innovative investments in times of trouble enabled E-mart to grow well despite the national economic crisis.

\subsubsection{Low cost operation}

In order to effectively manage many stores, success in operation and distribution system was crucial. The chain operation system resulted in cost reduction and early profits, which again contributed to expansion of stores under the multi-store strategy. To reduce the store operation costs further, E-mart actively took advantage of owning the largest number of stores in Korea and its buying power and achieved the lowest price. It also standardized the appliances and arrangement for all of its stores which contributed to lowering operation costs.

In addition, although they applied the department store POS (point-of-sale) system initially, as the number of stores increased, a customized E-mart POS system became valuable. The company developed an exclusive system suitable for retailer operation to improve real time information of products and reduce customers' waiting time. As the products become more diverse, the company created a brand new product system and introduced the concept of unit control in 1998.
One example is the E-mart engine system, which provides real-time information for more than 15,000 individual products. Such efforts enabled efficient low-cost operation, which also played an important role for the success of low price positioning.

\subsubsection{Merchandising}

Merchandising includes everything related to supplying products for sale including product selection. E-mart, in order to enhance its price competitiveness, minimized the distribution process by direct transaction with manufacturers. Although they had purchased products through an intermediate vendor in the past rather than manufacturers because the distribution system was not prepared properly, since 1998, the company minimized the logistical costs by directly dealing with the manufactures. Also, although it did not make a big contribution to the company's bottom line, private brand (PB) product development helped $\mathrm{E}$-mart provide inexpensive and good quality products.

\subsubsection{Customer satisfaction program based on low-prices}

E-mart, through various methods, tried to satisfy consumers by keeping the prices low (see Table 1). However, they did not stop here and for the first time in Korea, carried out customer satisfaction programs such as lowest price gua- 
〈Table 1〉 Customer Satisfaction Program of E-mart

\begin{tabular}{|c|c|c|}
\hline Program & time & Contents of Program \\
\hline Low price guarantee & May 1997 & $\begin{array}{l}\text { The compensation system when the products of E-mart is } \\
\text { more expensive than same products from different store }\end{array}$ \\
\hline Guarantee for freshness & May 1997 & $\begin{array}{l}\text { The system of } 1 / 2 \text { shorten expiry date autonomously. } \\
\text { selling the product with high degree of freshness }\end{array}$ \\
\hline $\begin{array}{l}100 \% \text { exchange or refund } \\
\text { system for unsatisfactory } \\
\text { products quality }\end{array}$ & June 1997 & $\begin{array}{l}\text { The system of exchange and refund regardless of the day } \\
\text { of purchase when the product purchased from E-mart is } \\
\text { unsatisfactory }\end{array}$ \\
\hline $\begin{array}{l}\text { Compensation for } \\
\text { miscalculation }\end{array}$ & June 1997 & $\begin{array}{l}\text { The compensation system of } 5,000 \text { won gift card when } \\
\text { error in calculation occurred }\end{array}$ \\
\hline
\end{tabular}

rantee, freshness satisfaction guarantee, 100\% exchange and refund for unsatisfactory products, and compensation for miscalculation, simultaneously establishing the low-price image and trust in products.

\subsection{The Result of the 1st Crisis Management - Opening the New Era of Distribution Industry}

The long-lasting economic recession strengthened E-mart's positioning of lowest price, and many companies began to enter the retailer business after watching E-mart's success. The success of E-mart opened the new era of distribution for Korea and brought innovation to the systems and logistics of the distribution industry, making a big mark in the history of Korean distribution industry.

Also, the lowered price helped make prudent purchase and bundle purchase a norm, and customers began to cope with the inconveniences of traveling a longer distance for better quality and lower priced goods. Finally, the power to set the price was shifted from manufactures to retailers, including E-mart, and to consumers. Although initially there was much conflict with manufacturers who had to take the burdens of cost cuts, but later on, this encouraged management innovation of manufactures that created products, package, and exclusive logistical systems for retailers. From then on, manufacturers steadily worked on management innovation to enhance competence. Therefore, growth of E-mart changed not only the distribution industry but also the relationship among manufacturers, distributors, and consumers, and also improved the quality of product and distribution as well as life of consumers.

\section{The 2nd Crisis during Mainstream Market Competition}

As the domestic distribution market was completely opened to overseas competition in 1996. 
starting with Macro and Carrefour, foreign discount stores like Walmart began to enter into the Korean market with advanced distribution systems and significant funding. Many experts predicted that foreign giant enterprises were going to dominate the retail industry in Korea as they considered what had happened in Taiwan when Taiwan had opened its distribution market to foreign competition.

However, in the end, it was Walmart that raised the white flag and handed over its businesses in Korea to E-Mart. How did this unprecedented defeat of Walmart occur? The main factor that led E-mart to triumph over its strongest competitor, Walmart, was E-mart's development of a new positioning as 'Korean style discount store' based on a deep understanding of Korean customers. Winning this competition with Walmart further led E-mart to gain a high level of trust from customers, which consequently. elevated E-mart's position as the number one discount store in Korea in the customers minds.

\subsection{The 2nd Crisis - the World Biggest Discount Store Walmart Came to Korea}

After the South Korean government had implemented the policy of foreign investment liberalization in 1993, the domestic distribution market was completely opened in 1996 . The request of opening domestic distribution market had been continuously raised by America and EC since 1983(see Table2).

Due to the Uruguay Round negotiation, the pressure of opening the Korean domestic market was getting stronger. Thus, government had committed to a step-by-step market opening plan and finally announced a complete distribution market opening to overseas on January $1^{\text {st }} .1996$.

Accordingly, starting with French company Macro's expansion to the Korea market in 1996. Carrefour opened its first department in Bucheon in the same year in July. In 1998, the world's biggest discount store, Walmart entered into the

〈Table 2〉 The Steps of Opening Korea's Distribution Market

\begin{tabular}{|c|c|c|}
\hline Time & Regulation & Major contents \\
\hline July 1981 & $\begin{array}{l}\text { Implementation limit of permit foreign } \\
\text { investment }\end{array}$ & $\begin{array}{l}\text { Admit only retail trade single items, shop } \\
\text { size smaller than } 330 \mathrm{~m}^{2}\end{array}$ \\
\hline October 1982 & Extension of limit range & Extension of shop size smaller than $660 \mathrm{~m}^{2}$ \\
\hline July 1984 & $\begin{array}{l}\text { Abolition of limit handling item } \\
\text { Implementation limit of the number of store }\end{array}$ & Admit single shop, under shop area $700 \mathrm{~m}^{2}$ \\
\hline July 1991 & $2^{\text {nd }}$ open distribution market & Admit below 10 shops, under shop area $1,000 \mathrm{~m}^{2}$ \\
\hline July 1993 & $3^{\text {rd }}$ open distribution market & Admit below 20 shops, under shop area $3,000 \mathrm{~m}^{2}$ \\
\hline January 1996 & full-open distribution market & $\begin{array}{l}\text { Complete abolition of limitation for the } \\
\text { number and size of shop }\end{array}$ \\
\hline
\end{tabular}

(*Source: Samsung Economic Research Institute 20 years corporate management in Korea) 
market by merging with Macro Korea. Followingly, E-mart entered the new era of competitions with these major foreign discount stores.

Walmart had a very strong logistics management system that could supply the lowest cost products acquired from venues around the world expeditiously using satellite technology that connects its 3500 stores worldwide. Competition with Walmart posed a threat greater than when the national economic crisis hit Korea.

Many experts had predicted that foreign discount stores were going to win the competition with E-mart and dominate the Korean market as was the case with Taiwan. With possibilities of completely losing the market to those foreign companies, a sense of crisis hovered around the market.

The competition with Walmart, a dinosaur company in the distribution industry, started off in a heated manner. Intense competition for lower prices began between Walmart and Emart. Especially, Walmart intensely pressured E-mart by offering up to a $30 \%$ of discount at first. In response, E-mart monitored the price of Walmart's major items in real time to offer products at a yet cheaper price. Moreover, the competition with Carrefour with its aggressive Hi-Low price policy was a big burden for E-mart to bear. The employees of $\mathrm{E}$-mart worked intensely and repeatedly worked overtime to preserve their stake in the Korean market.

\subsection{The Strategy of E-mart to Overcome the Crisis- Positioning Strategy of 'Korean Style Discount Store'}

In order to survive in competition with foreign discount stores, E-mart began to establish their positioning as a 'Korean style discount store'. Since Walmart is famous for its EDLP strategy, E-mart knew that a single-pronged, low-price positioning is insufficient to surmount Walmart. Thus, E-mart needed more than just a low-price positioning. This led E-mart to develop a new positioning that targets 'Korean housewives.' Since Korean housewives usually go grocery shopping on a daily basis (as opposed to a weekly basis) to prepare meals, a warehouse-styled store selling only industrial products could not fully satisfy their needs. E-mart knew that if grocery shopping became available in a discount store, it would readily attract housewives into their stores. Even though Walmart had a superior logistics chain network complemented by a satellite system, it had an Achilles' heel, the fresh food line, which is essential to grocery shopping. Therefore, E-mart had a chance to earn a differentiated core competence by reinforcing the fresh food line and building up a favorable environment for Korean consumers.

\subsubsection{Reinforcing fresh food line}

In order to enable grocery shopping at a discount store, offering fresh foods such as fishes 
and vegetables was essential. However, although Walmart and Carrefour realized the importance of fresh food to their customers, they were tied to the uniform policy of the head office which aimed to manage every Walmart on the globe in an standardized manner. E-mart actively pursued this opportunity. In 1998, while other competitors gave cooperative firms the responsibility to deliver fresh food to their respective stores, E-mart came up with a 'direct operation and management of fresh \& cooked foods' line. and started to specialize and make more efficient the management of quality and human resources (see Figure 3).

Through the direct management, E-mart simultaneously pursued higher quality of goods and lower prices and provided differentiated goods that few companies could match through direct management of fresh food. In addition, E-mart implemented the ' 3 customer satisfaction systems on fresh food' as a way to prove their confidence and build customer trust in their fresh food products. Particularly, in the case of fishes and vegetables, for which main- taining freshness is the critical factor, E-mart adopted the principle of selling products the same day they came in. To this end, small quantities were sold each day, and leftover fresh food was discarded in order to guarantee freshness to every customer in every instance (see Table 3).

In addition to direct management of produce, E-mart devoted a significant effort to develop its very own temperature and humidity maintenance system, called the Cool Chain system. which guarantees constant temperature from the point of procurement of the product, to processing, delivery, and finally to display at the stores. As constant maintenance of the optimal temperature is a major factor that determines freshness of grocery foods, E-mart further distanced their competitors in freshness.

Furthermore, E-mart enhanced sales and maintained a steady level of profit margins by cutting prices, aggressively exposing the goods through POP. By adopting a smart POP strategy, its POP displays clearly communicated to customers that their fresh food products such

〈figure 3〉 Reinforced E-mart Fresh Food Line

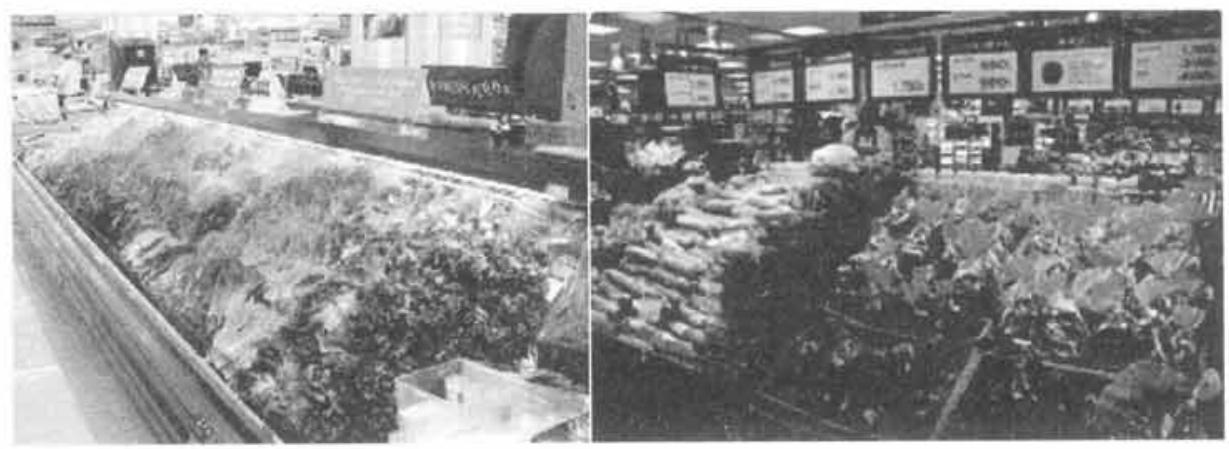


〈Table 3〉 Customer Satisfaction System for Fresh Food

\begin{tabular}{|c|c|c|}
\hline \multicolumn{2}{|c|}{ Customer satisfaction system for fresh food } & Product(total 1000 items) \\
\hline \multicolumn{2}{|c|}{$\begin{array}{l}\text { Products that is subject to be destroyed } \\
\text { in the case of unsold after the day }\end{array}$} & $\begin{array}{l}\text { Strawberry, cherry, cabbage. Korean cabbage, spinach, } \\
\text { parsley, garlic, Korean beef, pork, mackerel, hair tail etc. }\end{array}$ \\
\hline \multirow{4}{*}{$\begin{array}{l}\text { Products display } \\
\text { date Labeling }\end{array}$} & $\mathrm{D}+1$ & Grape, Korean melon, ripe persimmon, plum, mushroom chili etc. \\
\hline & $\mathrm{D}+2$ & $\begin{array}{l}\text { Sweet persimmon, mandarin orange, watermelon, orange. } \\
\text { potato, sweet potato etc. }\end{array}$ \\
\hline & $\mathrm{D}+3$ & Bag apple, pear, quince, ginger etc. \\
\hline & $\mathrm{D}+4$ & Onion, garlic, pumpkin type, chicken etc. \\
\hline \multicolumn{2}{|c|}{ Sugar content Labeling } & $\begin{array}{c}\text { Apple, pear, persimmon, strawberry. Korean melon, } \\
\text { pineapple, banana etc. }\end{array}$ \\
\hline
\end{tabular}

as vegetable, fish, fruit, etc., came directly from the place they were produced without any intermediaries. For example, squids were line caught and handled by E-mart's own fishing boats and were rapidly delivered to E-mart fresh food corners still alive. Its displays also emphasized that if customers were not satisfied with the product's freshness they could return products anytime for a guaranteed full refund or exchange. Since there were no such informative POP displays in Walmart or Carrfour. E-mart was able to deliver a strong and differentiated message that E-mart prioritized people's wellbeing through acquiring the freshest products.

The strategy to make fresh food really fresh worked. Consumers began to appreciate the efforts of E-mart as people felt that in E-mart they could get the freshest products. Initially, there was a cannibalization between E-mart and the Shinsegae. However, its gain in terms of building a clear image as the best fresh food provider, especially against the big giant, Wal- mart, far exceeded the costs of cannibalization. Many loyal customers of Walmart or Carrrefour were attracted to E-mart because of the fresh food corners at E-mart. The focus on building a clear advantage in the fresh food line became one of the most significant factors that contributed to E-mart's success against the giant Walmart as well as other foreign competitors. This kind of innovative effort, coupled with passion to serve customers right. made E-mart incredibly different from the other competitors including the giant, Walmart.

\subsubsection{The store layout designed for Korean}

The initial stores of E-mart were in warehousestyle resembling those of foreign discount stores such as Walmart and Carrefour where goods were sold in large-scale. However, Korean customers did not like the high display stand and a less-than-furnished interior of a typical warehouse-styled venue. While foreign discount 
stores maintained the store's uniform design used globally according to the policy of the head office, E-mart proceeded to dramatically change the store layout to reflect the tastes of their Korean customers. The first E-mart in Changdong, which housed a $2.4 \mathrm{~m}$ tall display mimicking the tall display used at foreign discount stores, lowered the height of their display to be about $1.5 \mathrm{~m}$ taking into consideration the average height of their Korean customers. Furthermore, E-mart newly placed ceiling skin and developed interior for a luxurious atmosphere and raised the intensity of illumination for the lights. E-mart reinforced convenience facilities such as the customer lounge, lactation room, and restroom for customers' convenience. E-mart also changed from large-scale product sales to small unit and bundle product sales in accordance with the Korean's consumption habit. These efforts worked in tandem to differentiate E-mart from the warehouse, do-it-yourself, and unfurnished style of the foreign competitors' stores.

\subsubsection{Customer satisfaction management based on differentiation from competitors}

E-mart tried to differentiate itself from competitors through customer satisfaction management, a reinforced fresh food line, and aggressive pursuit of the 'Korean style discount store'. As the distribution giant Walmart entered and competition with other domestic discount stores be- came intense, a set of powerful differentiating strategies became necessary. Specifically, E-mart felt the need to change its marketing strategy from mass marketing to a local-oriented marketing that fully understands the needs and values of local residents in order to provide more efficient service. Thus, E-mart conducted various local-friendly marketing so as to play a role as a local community center, not merely a place for shopping. For instance, a local community mileage system that donated $5 \%$ of sales to local community organizations or welfare facilities that installed donation boxes in $\mathrm{E}$-mart stores had a very positive response from customers. In addition, E-mart financially sponsored underprivileged students through a scholarship program and performed various eco-friendly activities such as helping to preserve XX mountains and brooks and cleaning streets. Furthermore, in order to enhance customer satisfaction, E-mart newly implemented systems such as a reward system for reporting the lowest price among its competitors, defective goods, and failure to keep a promise. This new change in customer satisfaction systems reflects a larger shift from a priceoriented competition to a non-price-oriented competition for discount stores. Consequently, E-mart sharpened its competitive edge in competition with Walmart as well as other domestic companies by being socially aware and responsible for local society, providing high-quality goods, and implementing systems for keeping promises with their customers. 
4.3 The Result of the 2nd Crisis Management: Takeover of Walmart Korea and Explosive Sales

On May $22^{\text {nd }}, 2006$, Walmart Korea finally sold its 825 billion won shares and 16 stores in Korea to E-mart and left the Korean market (see Figure 4). Foreign media including the New York Times compared this shocking case to the famous biblical account of David beating Goliath. The Wall Street Journal analyzed the success of E-mart and attributed the success to 'spacious division, lows display counter, colorful and bright atmosphere, and noisy and festive like outdoor marketplace - features that focused on the Korean consumer's taste and differentiated E-mart from its competition. After having changed continuously in response to the taste of Korean consumers, E-mart's 'Korean style discount store' positioning strategy finally achieved great success. E-mart immediately began to change the Walmart stores it had acquired into a Korean-styled discount store. In addition to increasing store lighting and lowering the heigh of the counters, E-mart placed fresher products and created an aesthetically sophisticated interior. and succeeded in bringing back customers who previously turned away from Walmart.

Furthermore, during this time, E-mart began to radically expand the number of their stores. Since 2000, E-mart opened nearly 10 stores per year and became the largest and best company in the distribution industry. From 14 stores and domestic sales of 1,277.6 billion won in 1998. E-mart grew by more than 7 times recording 103 stores and domestic sales of 8,246.7 billion won in 2006. In 2003, total sales from discount stores became greater than that of the department stores. It would have been impossible for the sales per store to soar if it were not for the

〈Figure 4〉 Changes in Sales and Number of Stores after E-mart Took over Walmart

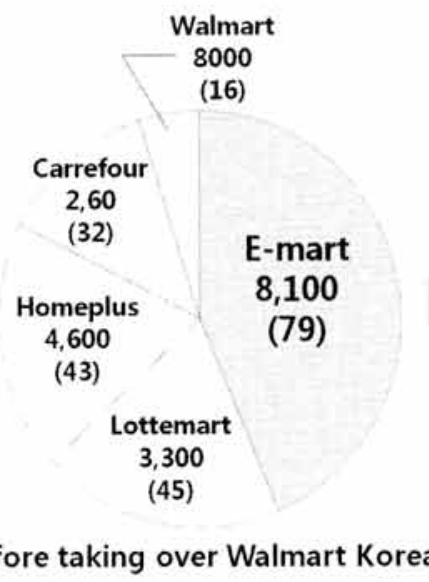

Before taking over Walmart Korea

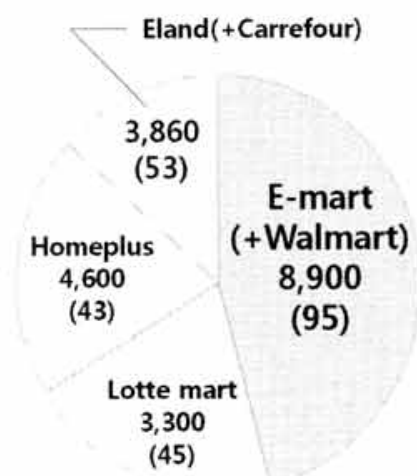

After taking over Walmart Korea

- unit: billion won (sales as of 2005)

( ) : number of stores as of May 2006 
consistent and trustworthy pricing policy and customer-oriented marketing. E-mart made a huge impact on the distribution and manufacturing industries with the shift in buying power and became the 'top Korean discount store' in the customers' minds.

\section{Conclusion and Implications}

We have reviewed how Shinsegae started a large discount store business and how this discount store, E-mart, turned major difficulties into major opportunities. Shinsagae foresaw a paradigm shift in the Korean distribution industry and pioneered opportunities for the Korean discount store business. Although E-mart experienced two crises since they established their first discount store in 1993, it turned out that these crises ultimately provided the pivot for even bigger success with its strategies.

In our examination of the E-mart case, we could clearly see E-mart's competence and spirit that allowed it to turn crises into advantageous opportunities. E-mart attracted the customers who wanted value-oriented consumption by its positioning as the "Lowest price discount store", when consumer sentiment was frozen under the economic crisis. Furthermore, when a largescale foreign discount store like Walmart entered the Korea market, E-mart built its core competencies as the 'Korean style discount store'.
These ingenious positioning and efforts resulted in E-mart taking over their archrival, Walmart, and forced the global Goliath to exit the Korean market.

The case of E-mart's effective crisis management teaches many important lessons and a few core lessons that apply to many companies. One such lesson is the importance of positioning which enabled E-mart to turn crises into opportunities. Granted, the strategy of positioning as the 'Korean style discount store', or 'Lowest price discount store was possible due to overall support with cost reduction, development and management of their own system, an apprentice educate system, etc. based on an excellent selection of location of the store and efficient distribution systems. Still, the positioning strategy was truly ground breaking in distancing E-mart from its competitors. This serves as a good example to the companies currently in a stagnant situation or crisis facing major competitors.

E-mart became the best discount store in Korea by achieving success in what can be named as the foresight competition, new power preparation competition, early market competition, and mainstream market competition, as described by Kim (2005, 2011). E-mart currently holds great business prowess in Korea and is expanding yet to the growing Asian markets such as the one in China. Its ultimate success in global markets depends on how well it prepares for a paradigm shift as was the case in Korea. If a new venture in the retail industry foresees big 
opportunities and threats concealed in the paradigm shift and prepares accordingly for the future, it may have the opportunity to take away the lead from E-mart. Therefore, E-mart should continue focusing on the foresight competition as it did before, as examined in this case study. Continuing its model of success, we strongly believe that E-mart will lead the distribution industry with their new and differentiated positioning strategy.

This study contributes to the academic literature by analyzing the success of E-mart from a unique perspective. Although the success story of E-mart was documented in several papers and case studies, this study focused on how Emart overcame the two critical crises, economic crisis and the entry of the giant global company, Walmart. Given the global economic downfall and the growing global competition, the two crises could come any time to any company, regardless of their respective industry. Lessons from our case study may help those companies overcome obstacles, see opportunities from threats, and successfully sail through the coming turbulent waves.

〈Recieved July 24. 2012〉

〈Revised September 07. 2012〉

〈Accepted September 13. 2012〉

\section{References}

Ahn, Kwang Ho and Ha Neol Lee (2011), "The Effect of Perceived Shopping Value Dimensions on Attitude toward Store, Emotional Response to Store Shopping, and Store Loyalty," Asia Marketing Journal, 12(4), 137-164.

Christensen, Clayton M., Scott Anthony and Eric Roth (2004), Seeing What's Next?: Using Theories of Innovation to Predict Industry Change. MA: Harvard Business School Press.

Hwang, Soon ho, Jong Chul Oh and Sung Joon Yoon(2012), "Study on the Relationships Among Perceived Shopping Values, Brand Equity, and Store Loyalty of Korean and Chinese Consumers: A Case of Large Discount Store," Asia Marketing Journal, 14 (2), 209-237.

Harvard Business Review (1999), Harvard Business Review on Entrepreneurship. MA: Harvard Business Review Press.

Hong, Chung Seop (2010), "Rebranding Strategy in Distribution Industry," $2^{\text {nd }}$ WK-MIC2010 Rebranding Conference

Jim, Collins (2001), Good to Great. New York:

Harper Business Publisher.

Jim, Collins (2009), How the Mighty Fall. New

York: Harper Collins.

Jung Ku Hyun (2008), 20 Years Corporate

Management in Korea, Samsung Economic 
Research Institute,

Jun, Ok Pyo and Chung K. Kim (2011), "The Effect of Manufacturers' Dealer Promotion and Relationship Characteristics on Distributors' Satisfaction and Commitment," Services Marketing Journal, 4(2), 69-90.

Kim, Chung K. (2005), Marketing for the Future, Kyobo Books.

Kim, Chung K. (2011), Prepare for Your Wings, 1000 Years' Treasure.

Kim, Chung K., Greg Pratt, Mina Jun, Miyea Kim and Jeongsoo Han(2012), "Searching for the Korean Ways of Making a Dent in the Universe: Analysis of Top Winning Korean Brands," in How Korean Brands Soar all over the World, Chung K. Kim, Greg Pratt, Mina Jun, Miyea Kim and Jeongsoo Han,eds., The 1000 Years' Treasure, 1-8.

Kim, Hoon (2005), "A Case Study of E-mart's Marketing on Jecheon Market," Korea Business Review, 8(2), 39-56.
Kim, Joo Tae (2009), "Contingency Approach to Localization of MNC: A Case from Korean Discount Stores," International $\mathrm{Ma}-$ nagement Review, 13(2), 57-87.

Leenders, Michael R. \& James A. Erskine(1989), Case Research: The Case Writing process, $3^{\text {td }}$ edition, School of Business Administration, University of Western Ontario.

Mang, Myung Kwan(2007), Hidden Secrets of E-mart $100^{\text {th }}$ Store, Vision Korea.

Oh, Se Young and Il San Kim(2003), "A Comparative Analysis on the Marketing Mix Strategies of Foreign and Domestic Super Discount Stores," Journal of Trade Research, 28(2), 185-220.

Suk, Kwan Ho, Song Oh Yoon and Ji Eun Koo (2012), "EDLP or HiLo ? The Influence of Consumer Psychological Variables on Store Choice," Journal of Korean Marketing Association, 27(1), 67-84. 


\section{〈Appendix > Changes in Number of Stores and Sales of E-mart}

\begin{tabular}{|c|c|c|c|c|c|c|c|c|c|c|c|}
\hline \multicolumn{2}{|c|}{ Year } & 1993 & 1994 & 1995 & 1996 & 1997 & 1998 & 1999 & 2000 & 2001 & 2002 \\
\hline \multirow{3}{*}{ Stores } & Korea & 1 & 2 & 4 & 6 & 9 & 13 & 19 & 27 & 50 & 41 \\
\cline { 2 - 11 } & China & 0 & 0 & 0 & 0 & 1 & 1 & 1 & 1 & 1 & 1 \\
\cline { 2 - 11 } & Total & 1 & 2 & 4 & 6 & 10 & 14 & 20 & 28 & 51 & 42 \\
\hline $\begin{array}{c}\text { Revenue } \\
(100 \text { million won })\end{array}$ & 52 & 626 & 1,873 & 3,379 & 7,046 & 11,387 & 17,049 & 28,852 & 40,711 & 55,203 \\
\hline
\end{tabular}

\begin{tabular}{|c|c|c|c|c|c|c|c|c|c|c|}
\hline \multicolumn{2}{|c|}{ Year } & 2003 & 2004 & 2005 & 2006 & 2007 & 2008 & 2009 & 2010 & 2011 \\
\hline \multirow{3}{*}{ Stores } & Korea & 59 & 69 & 79 & 103 & 111 & 120 & 127 & 133 & 135 \\
\cline { 2 - 10 } & China & 1 & 2 & 4 & 7 & 19 & 18 & 24 & 27 & 27 \\
\cline { 2 - 11 } & Total & 60 & 71 & 83 & 110 & 121 & 138 & 151 & 160 & 162 \\
\hline $\begin{array}{c}\text { Revenue } \\
(100 \text { million won })\end{array}$ & 63,287 & 71,706 & 81,063 & 89,796 & 103,422 & 109,369 & 115,000 & 126,000 & 144,000 \\
\hline
\end{tabular}

